\author{
WANDA DUGIEL \\ Warsaw School of Economics, Poland
}

\title{
WTO AND SUSTAINABLE DEVELOPMENT: CONCEPT, POSSIBILITIES OF DELIVERING DEVELOPMENT GOALS, EFFECTS.
}

\begin{abstract}
:
The aim of this article is to examine the following issues: what will be the effects of the World Trade Organization (WTO) implementation of the goals of sustainable development objectives for developed and developing countries, and whether the goals of sustainable development formulated by the UN will enable further liberalization of international trade in the WTO.

The implementation of the UN Resolution 2015: "Transforming our world: the 2030 Agenda for Sustainable Development" by the developed and developing countries is very difficult and runs very slowly.

The postulate included in the Agenda 2030 about the necessity of countries' withdrawal from the use of some tools of trade policy, in particular export subsidies still in agricultural trade, was important. The use of export subsidies by developed countries has been a source of conflicts in international trade for many years. Developing countries emphasized losses due to competitive prices of agricultural products offered by developed countries on the international market.

The objectives of sustainable development take into account the need to include the WTO in activities that will reduce the level of poverty in the world. These objectives remain in line with the WTO objectives as set out in the preamble to the WTO Agreement. WTO activities for economic development have not produced the expected results. The Doha Development Round was supposed to lead to accelerated economic development of developing countries. The goals of the Doha Round of 2001 have not been achieved. The decision to eliminate export subsidies in agricultural trade adopted by the WTO in 2015 at the Ministerial Conference in Nairobi will not have a clear impact on the benefits for all developing countries or emerging economies with the potential to increase their share in international trade. An increase in prices for agricultural commodities on the international market may limit price competitiveness on agricultural commodities of exporting countries, including Brazil, China and India. Some of the least developed countries belong to net importers in agricultural trade.

The implementation of the other WTO sustainable development objectives will depend on the functioning of the special and differential treatment principle. The question of the interests of developing countries in complying with environmental protection standards, which will affect international trade, is controversial. Many developing countries will oppose the adoption of regulations supporting the trade in goods produced in accordance with environmental standards, in particular after the US withdrawal from the Paris climate agreement.
\end{abstract}

\section{Keywords:}

international trade, World Trade Organization, developed countries, developing countries

JEL Classification: F13 